\title{
The Role of Sodium Sulfate Supporting Electrolyte in Ammonium Transport and Reduction at Interface Between Platinum Cathode and Solution
}

Linji Xu ${ }^{1 *}$, Yunsong Pang ${ }^{2}$, Dezhao Huang ${ }^{2}$, Huichuan Zhuang ${ }^{3}$, Wenzong Liư ${ }^{4}$, Tengfei Luo ${ }^{2}$, Po-Heng Lee ${ }^{5}$, Li Feng ${ }^{1}$, Junchi Lu ${ }^{6}$

${ }^{1}$ Environmental Engineering Technology Research Center, Chongqing Academy of Ecology and Environmental Sciences,

Qishan Road 252, Yubei district, Chongqing, P. R. China.

${ }^{2}$ Department of Aerospace and Mechanical Engineering, University of Notre Dame, Notre Dame, Indiana 46556, United States

${ }^{3}$ Department of Civil and Environmental Engineering, The Hong Kong Polytechnic University, Hung Hom, Kowloon, Hong Kong SAR, P. R. China.

${ }^{4}$ Key Laboratory of Environmental Biotechnology, Research Center for Eco-Environmental Sciences, Chinese Academy of Sciences, Beijing 100085, China

${ }^{5}$ Department of Civil and Environmental Engineering, Imperial College London, London, U.K.

${ }^{6}$ Department of Electrical Engineering, University of Notre Dame, Notre Dame, Indiana 46556, United States

*Corresponding author: dophegood@gmail.com; phone: +86-88521315 


\section{Abstract}

Ammonium is a potential hydrogen fuel and can be recovered from high ammonium wastewater via electrodeionization (EDI) process. Since $\mathrm{NH}_{4}{ }^{+}$is a weak acid ion, sodium sulfate $\left(\mathrm{Na}_{2} \mathrm{SO}_{4}\right)$ is used as a supporting electrolyte to improve electrolyte's conductivity. This manuscript investigated the $\mathrm{NH}_{4}^{+}$behaviors in high $\mathrm{Na}_{2} \mathrm{SO}_{4}$ solution through electrochemical analysis methods and molecular dynamics (MD) simulations. Ionic strength increased, leading to a decreased ionic activity, and thus negatively influenced $\mathrm{NH}_{4}{ }^{+}$transportation with the increasing concentration of $\mathrm{Na}_{2} \mathrm{SO}_{4}$ solution. $\mathrm{Na}^{+}$ competitively occupied the place of electric double layer (EDL) and impeded $\mathrm{NH}_{4}{ }^{+}$to get closer to the electrode surface. Besides, water molecules played a critical role in determining the net charge density and the potential drop. The experimental tests and theoretical simulation demonstrated that $\mathrm{NH}_{4}{ }^{+}$reduction $\left(\mathrm{NH}_{4(a q)}^{+}+e^{-} \rightarrow 0.5 H_{2(g)}+N_{3(g)}\right)$ in the cathode was strengthened in the low concentration range $\left(0-0.25 \mathrm{M} \mathrm{Na}_{2} \mathrm{SO}_{4}\right)$ but inhibited in the concentration range of 0.5 $1.5 \mathrm{~mol} \mathrm{~L}^{-1}$.

Keywords Supporting electrolyte concentration, Ammonium transport and reduction, Electric double layer, Molecular dynamic simulation 


\section{Introduction}

2 The concentrated ammonium existing in wastewater and landfill leachate can be

3 recovered as ammonia and hydrogen gas via electrodeionization (EDI) [1]. $\mathrm{NH}_{3}$ generation

4 has two paths: (1) $\mathrm{NH}_{4}{ }^{+}$is reduced to proton and $\mathrm{NH}_{3}$ via a one-electron transfer process

5 in the EDI cathode (Eq. 1) [2]; (2) Water splits into $\mathrm{OH}^{-}$that reacts with $\mathrm{NH}_{4}^{+}$to generate

$6 \quad \mathrm{NH}_{3}$ (Eq.2 and Eq.3) [3]. $\mathrm{NH}_{4}{ }^{+}$reduction is more likely to occur other than water splitting

7 when EDI is process operated at the low applied voltage ( $<1.23 \mathrm{~V})$.

8

9

10

11 During $\mathrm{NH}_{4}{ }^{+}$reduction, slow mass transfer determines the generation of $\mathrm{NH}_{3}$ gas since

$12 \mathrm{NH}_{4}{ }^{+}$is a weak acid ion. To solve this issue, a strong electrolyte such as sodium sulfate is

13 usually added as the supporting electrolyte to enhance electrolyte's conductivity [2, 4-9].

14 However, the added co-ion often provokes a competition with the target ion. As reported

15 by Casadellà et al. who studied the cation completion of $\mathrm{K}^{+}, \mathrm{Na}^{+}$and $\mathrm{NH}_{4}{ }^{+}$in urine through

16 polymer inclusion membranes, the order of selective recovery $\left(\mathrm{K}^{+}>\mathrm{Na}^{+}>\mathrm{NH}_{4}^{+}\right)$and two-

17 fold flux in $\mathrm{Na}^{+}\left(4.5 \times 10^{-3} \mathrm{mmol} \mathrm{cm}^{-2} \mathrm{~h}^{-1}\right)$ over $\mathrm{NH}_{4}{ }^{+}\left(1.5 \times 10^{-3} \mathrm{mmol} \mathrm{cm}^{-2} \mathrm{~h}^{-1}\right)$ was observed

18 [10]. Liu et al. conducted a study on the competitive transport of $\mathrm{Na}^{+}$and $\mathrm{NH}_{4}^{+}$in

19 bioelectrochemical systems and concluded that $\mathrm{Na}^{+}$in anolyte facilitated the transport of

$20 \mathrm{NH}_{4}{ }^{+}$due to the Donnan equilibrium at cation exchange membrane-anolyte/catholyte

21 interfaces [9]. Rosasco et al. investigated cation competition in the electrical double layer 
22 (EDL) at a well-defined Pt (111) electrode surface and found the strength order of cation

23 retention, $\mathrm{Na}^{+}>\mathrm{NH}_{4}{ }^{+}$, which might be related to the hydrated radius of $\mathrm{Na}^{+}(3.58 \AA)$ over

24 that of $\mathrm{NH}_{4}{ }^{+}(3.31 \AA$ ) weakening electrochemical activities, e.g., charge density, dielectric

25 constant, and rate capability [11-15]. Besides, some researchers reported that the

26 accumulated $\mathrm{Na}^{+}$attracted to water molecules and built a compacted $\mathrm{Na}^{+}-\mathrm{H}_{2} \mathrm{O}$ layer,

27 which deterred the electrochemical reaction kinetics $[16,17]$. Others depicted that $\mathrm{Na}^{+}$

28 competitively reduced the effective current efficiency of $\mathrm{NH}_{4}{ }^{+}$and produced electrode

29 overpotential at a fixed electric current [18-21]. Therefore, the influences of $\mathrm{Na}^{+}$on the

30 behaviors of mass transportation in the EDL cannot be ignored when $\mathrm{Na}_{2} \mathrm{SO}_{4}$ is used as

31 the supporting electrolyte.

32 Mass transportation in the EDL is investigated through theoretical simulation other than

33 experimental tests due to the measuring difficulties of the transport coefficient and mass

34 quantification. The classical theories of the mass distribution in the EDL includes Fick's

35 diffusion laws, Nernst-Planck, and Nernst-Einstein equation. The latest theoretical

36 simulations such as molecular dynamics (MD) simulations built on EDL theories are

37 increasingly popular because simulations from the molecular level can deliver insightful

38 information about the interactions at the electrode interface. For instance, Soroosh and

39 Hai conducted MD simulations of flexible-boundary Quantum Mechanics/Molecular

40 Mechanics to reveal ion solvation and found that $\mathrm{NH}_{4}{ }^{+}$had a more significant discrepancy

41 in the extent of charge transfer (by about $0.3 \mathrm{e}^{-}$) and more extensive distribution than $\mathrm{Na}^{+}$

42 (0.1 e-) [12]. Soetardji et al. used the Langmuir model to study $\mathrm{NH}_{4}{ }^{+}$removal from

43 wastewater via sodium hydroxide modified zeolite mordenite and found that the 
44 competition from $\mathrm{Na}^{+}$decreased the removal efficiency of $\mathrm{NH}_{4}{ }^{+}$through the different

45 reaction mechanisms [21]. To date, however, $\mathrm{NH}_{4}{ }^{+}$transport at the interface of Pt-

46 solution under the different gradients of $\mathrm{Na}^{+}$concentration has not yet been well studied.

47 The objective of this study is to understand the mechanism of supporting electrolyte

48 concentration affecting $\mathrm{NH}_{4}{ }^{+}$behavior and provide the opportunity to elucidate the

49 related molecular-level mechanism. Therefore, we employed electrochemical tests

50 combined with $\mathrm{MD}$ simulations to examine the effects of $\mathrm{Na}_{2} \mathrm{SO}_{4}$ concentration on $\mathrm{NH}_{4}{ }^{+}$

51 migration, reduction, and electric properties of the cathodic EDL.

\section{Experimental tests and theoretical calculation}

\section{$53 \quad 2.1$ Experimental tests}

54 Equipment setup. Figure 1 shows the configuration of a sandwich-type EDI stack. The 55 working volume is $40.0 \mathrm{~cm}^{3}: 60.0 \mathrm{~mm} \times 60.0 \mathrm{~mm} \times 11.0 \mathrm{~mm}$, in which the $11.0 \mathrm{~mm}$

56 included a $10.0 \mathrm{~mm}$ distance between the anode and the cathode and $1.0 \mathrm{~mm}$ thick

57 silicone gaskets. The electrodes were titanium plates coated in a $0.02 \mathrm{~mm}$ thick layer of

58 platinum, with a $16.0 \mathrm{~cm}^{2}$ effective area. The original electrolyte was $0.25 \mathrm{M}$ ammonium

59 sulfate, which was then mixed with 0-1.5 M sodium sulfate supporting electrolyte at a

$60 \quad 25.0^{\circ} \mathrm{C}$ operating temperature. The conductivity was measured with a conductivity meter

61 (Shanghai Leici-Chuangyi Instrument and Meter Co., Ltd).

62 Cyclic voltammetry scanning. The tests of current density versus applied voltage were

63 carried out using the EDI stack as described above. The scanning electrolyte was the 
64 mixtures of fixed ammonium sulfate $(0.25 \mathrm{M})$ and changed the concentration of sodium

65 sulfate $(0.125-1.5 \mathrm{M})$. The reference electrode was $\mathrm{Ag} / \mathrm{AgCl}-217$ (INESA Scientific

66 InstrumentCo., Ltd) that has a double-salt bridge. The current was recorded and

67 analyzed by the electrochemical working station (CorrWare ${ }^{\circledR}$, Scribner Associates Inc.,

68 U.S.A.), as shown in Figure 1.

$69 \quad 2.2$ Computational methods

70 Electrode/electrolyte interface modeling. The simulation system was a three-dimensional

71 supercell with periodic boundary conditions, constructed in the Materials Studio software.

72 It was composed of Pt sheets $(50 \AA \times 50 \AA$ ) as electrodes and the electrolyte aligned in

73 parallel with an interlayer distance of $140 \AA$, shown in Figure SI-1(a). To simulate the Pt

74 electrode/electrolyte interface, water molecules and $\mathrm{NH}_{4}{ }^{+}$with different concentrations

75 of $\mathrm{Na}^{+}$and $\mathrm{SO}_{4}{ }^{2-}$ were added to the space between anode and cathode. Both anode and

76 cathode were Pt (100) surface consisting of 338 atoms, 7 layers for each pole. The

77 numbers of the atoms of the Pt-solution system are summarized in Table SI-1 and Table

$78 \mathrm{SI}-2$.

79 Equilibrium relaxation and data collection. MD simulations were performed using the

80 Atomic/Molecular Massively Parallel Simulator package (LAMMPS) at a temperature of

$81300 \mathrm{~K}$ and a pressure of $1 \mathrm{~atm}[3,22]$. The interatomic interactions were simulated using

82 Lennard-Jones ( $\sqcup$ ) potential as described in Eq. 4: 


$$
E=4 \xi_{L J}\left[\left(\frac{d_{L J}}{r}\right)^{12}-\left(\frac{d_{L J}}{r}\right)^{6}\right]
$$

84 Where $\xi_{\nu}$ and $d_{\nu}$ are the respective parameters of energy and length, as summarized in

85 Table SI-2. The electrostatic interaction between charged atoms was calculated using 86 Coulomb's law (Eq. 5) with the Coulombic interactions computed using the particle87 particle particle-mesh (PPPM) algorithm [23].

$$
E=\frac{C q_{1} q_{2}}{\varepsilon r}
$$

89 where $C$ is an energy-conversion constant, $q_{1}$ and $q_{2}$ are the charges carried by two atoms, $90 \varepsilon$ is the dielectric constant. Bonds and angles among atoms are held rigid using the SHAKE

91 algorithm [24]. Water molecules are simulated using the rigid SPC/E water model and the

92 Pt atoms are held fixed [25]. The NVT ensemble simulations were carried out at $300 \mathrm{~K}$

93 with Langevin thermostats for $1.0 \mathrm{~ns}$ with a $0.5 \mathrm{fs}$ time step size. NPT ensemble 94 simulations at $1 \mathrm{~atm}$ and $300 \mathrm{~K}$ were then carried out.

95 After the systems reaching the thermal equilibrium state, we collected data (i.e., mass 96 density, number density, mean square displacement (MSD), radial distribution function 97 (RDF), etc.) during an NVE ensemble for $0.5 \mathrm{~ns}$, as displayed in Figure SI-1(b) and Figure $98 \mathrm{SI}-1(\mathrm{c})$. A voltage of $3.0 \mathrm{~V}$ was applied to the solution by applying the corresponding 99 electrostatic forces $F=q E$ on each charged atom. For post-processing the results, the 100 channel was split into a set of bins (1.0 $\AA$ in width) along the direction (x) perpendicular 101 to the Pt surface. The mass density $\rho(x)$ was then used to analyze the EDL structures. 
103 Charge density. Charge density is an important property for analyzing EDL. According to 104 the axial number density of atoms, the total charge density profile, $\sigma_{q(x)}$, is contributed by 105 ions and water, as expressed in Eq. 6.

$$
\sigma_{q(x)}=\sum_{i \ni s u r f} \sigma_{i}(x) q_{i}+\sigma_{O}(x) q_{O}+\sigma_{H}(x) q_{H}
$$

where $\sigma_{i}, \sigma_{O}$, and $\sigma_{H}$ are the number densities of ions, water-oxygen, and water-hydrogen,

108 respectively. $q_{i}, q_{O}$, and $q_{H}$ are the charges carried by them, respectively.

Electric field and potential profiles. Electric field strength and potential oscillate with

110 variations in charge density. The electric field $\left(E_{q(x)}\right)$ component normal to the Pt surface

111 was calculated by integrating the net charge density as described by Eq. 7.

$$
E_{q(x)}=-\left(1 / \epsilon_{0}\right) \int_{-\infty}^{x} \sigma_{q}\left(x^{\prime}\right)\left(x-x^{\prime}\right) d x^{\prime}
$$

113 The potential was computed by integrating the Poisson equation in one dimension, as 114 described in Eq. 8.

$$
\frac{\partial^{2} V(x)}{\partial x^{2}}=-\frac{\sigma(x)}{A_{P t} \varepsilon_{0}}
$$

116 where $\sigma(x), A_{P t}$, and $\varepsilon_{0}$ are the net charge density, the size of the Pt sheet and the vacuum

117 dielectric constant, respectively. Eq. 8 was numerically integrated to obtain $V(x)$, as shown

118 in Eq. 9 using $x=L / 2$ (the middle of the channel) as a reference that was regarded as zero

119 charge density (Eq. 9). 


$$
V(x)=\iint_{L / 2}^{x} \frac{\sigma(x)}{A_{G} \varepsilon_{0}} d x^{2}
$$

121 Mean square displacement (MSD). MSD is expressed by $\mathrm{R}^{2}$ that is a measure of the length

122 of the path of a molecule traveled. It is directly related to the diffusion coefficient of this

123 molecule through Einstein's equation [26]. As a result, MSD can be used to gain insight

124 into transport phenomena [27]. MSD in MD simulation can be calculated as:

$$
R^{2} \equiv\left\langle\left(x-x_{0}\right)^{2}\right\rangle=\frac{1}{N} \sum_{n=1}^{N}\left(x_{n}(t)-x_{n}(0)\right)^{2}
$$

126 where $N$ is the number of particles to be averaged, $x_{n}(0)=x_{0}$ is the reference position of

127 each particle, and $x_{n}(t)$ is the position of each particle at time, $t$. By tracking the molecular

128 positions, the MSD of the particles was calculated to quantify ion and water transport in 129 the EDL.

130 Diffusion coefficient. The diffusion coefficient is the rate of mass transport, as described 131 by the slope ( $r$ ) of the MSD versus $t$ curves (Eq. 11) from Einstein's equation.

$$
D=\lim _{t \rightarrow \infty} \frac{1}{6 t}\left\langle[r(t)-r(0)]^{2}\right\rangle
$$

133 where $r$ and $t$ are atomic compound position and time, respectively.

134 Radial distribution function (RDF). RDF is defined as Eq. 12.

$$
g(r)=\rho(r) / \rho
$$

136 where $\rho(r)$ is the local number density of atoms at a given radius; $\rho$ is the average mass 137 of the whole solution. 


\section{Results and discussion}

1393.1 Ion transport in interfacial solution via experimental tests

$140 \quad 3.1 .1$ Solution properties

141 The influence of $\mathrm{Na}_{2} \mathrm{SO}_{4}$ concentration on ion strength and activity coefficient $[28,29]$ of

$142 \mathrm{NH}_{4}{ }^{+}\left(\mathrm{z}_{\mathrm{i}}=1, \mathrm{a}_{\mathrm{i}}{ }^{0}=0.3\right.$ and $\left.\mathrm{b}_{\mathrm{i}}=0.2\right)$ was plotted (Figure 2(a)). The ion strength is strengthened

143 from $1.0 \mathrm{M}$ at $0.125 \mathrm{M} \mathrm{Na}_{2} \mathrm{SO}_{4}$ to $5.5 \mathrm{M}$ at $1.5 \mathrm{M} \mathrm{Na}_{2} \mathrm{SO}_{4}$. However, the activity coefficient

144 of $\mathrm{NH}_{4}{ }^{+}$goes down from 0.3 to 0.05 , signifying that the increased concentration of

145 supporting electrolyte negatively affected the activity of $\mathrm{NH}_{4}{ }^{+}$. The concentration also

146 influenced $\mathrm{pH}$ value and conductivity. As shown in Figure 2(b), $\mathrm{pH}$ value experiences a

147 sharp increase as the concentration of $\mathrm{Na}_{2} \mathrm{SO}_{4}$ solution below $0.5 \mathrm{M}$ but a smooth increase

148 to 9.99 at $1.5 \mathrm{M}$, indicating that increasing the concentration of $\mathrm{Na}_{2} \mathrm{SO}_{4}$ solution does not

149 bring an apparent effect on $\mathrm{pH}$ value in the concentrated range.

$150 \quad 3.1 .2$ Ion migration

151 The changed characteristics caused by ion strength and activity impacts ion transport in 152 the interfacial solution. Ion migration can be described through viscosity and mobility.

153 Viscosity calculated based on Jones-Dole`s equation [30-32] experiences a slow 154 growth from $80 \mathrm{mPas}$ below $0.25 \mathrm{M}$, and a sharp climb to $330 \mathrm{mPas}$ at $1.5 \mathrm{M}$. The visible 155 increase in dynamic viscosity reflects that increasing concentration lowers the liquidity of

156 bi-electrolyte so that produces a high resistance to ion migration (Figure SI-2). The 157 variations of ion mobility and number calculated according to $\mu=e z / 6 \pi \eta r$ [33] were 
158 summarized in Table 1. $\mathrm{NH}_{4}^{+}$has an increase in mobility from $1.01 \mathrm{~m}^{2} \mathrm{~V}^{-1} \mathrm{~s}^{-1}$ to $1.49 \mathrm{~m}^{2} \mathrm{~V}^{-}$ $159{ }^{1} \mathrm{~s}^{-1}$ at $0.125 \mathrm{M}$, but a drop to $1.27 \mathrm{~m}^{2} \mathrm{~V}^{-1} \mathrm{~s}^{-1}$ at $1.5 \mathrm{M}$. $\mathrm{Na}^{+}$and $\mathrm{SO}_{4}{ }^{2-}$ have drops to 1.63 $160 \mathrm{~m}^{2} \mathrm{~V}^{-1} \mathrm{~s}^{-1}$ and $0.81 \mathrm{~m}^{2} \mathrm{~V}^{-1} \mathrm{~s}^{-1}$, respectively. Concerning transport number, both $\mathrm{NH}_{4}^{+}$and $161 \mathrm{SO}_{4}{ }^{2-}$ decreases from 0.17 and 0.5 at $0.125 \mathrm{M}$ to 0.08 and 0.28 at $1.5 \mathrm{M}$, respectively.

162 However, $\mathrm{Na}^{+}$increases to 0.64 at $1.5 \mathrm{M}$. The results of ion transport reveal that the large 163 hindrance may lead to the lack of $\mathrm{NH}_{4}^{+}$as an electron carrier at the cathode interface, 164 which has been elaborated by Pal [16].

1653.2 lon transport in electric double layer via MD simulation

$166 \quad 3.2 .1$ lon diffusion coefficient

167 Due to the limitation of experimental detection, the diffusion coefficient was elaborated 168 using MD simulation. The migrations of $\mathrm{NH}_{4}{ }^{+}$and $\mathrm{Na}^{+}$in the EDL were quantified via the 169 MSD values of $\mathrm{N}$ and $\mathrm{Na}$ atoms. The average MSD slope of the $\mathrm{N}$ atoms grows from 2.1874 $170 \times 10^{3}$ at $0 \mathrm{M}$ to $3.1687 \times 10^{3}$ at $0.25 \mathrm{M}$ but drops to $1.457 \times 10^{3}$ at $1.5 \mathrm{M}$ in $0-1.5 \mathrm{M} \mathrm{Na}_{2} \mathrm{SO}_{4}$ 171 and as a function of time of $0.5 \mathrm{~ns}$ (Table SI-3). The corresponding diffusion coefficient of $172 \mathrm{NH}_{4}{ }^{+}$increases from $2.1874 \times 10^{-9} \mathrm{~m}^{2} \mathrm{~s}^{-1}$ at $0 \mathrm{M}$ to $5.2812 \times 10^{-9} \mathrm{~m}^{2} \mathrm{~s}^{-1}$ at $0.25 \mathrm{M}$ but falls 173 to $2.4319 \times 10^{-9} \mathrm{~m}^{2} \mathrm{~s}^{-1}$ at $1.5 \mathrm{M}$ as displayed in Figure 3(a) and Figure 3(b). The largest 174 diffusion coefficients are obtained at $0.25 \mathrm{M}$. For the over-concentrated $\mathrm{Na}_{2} \mathrm{SO}_{4}$ 175 electrolyte $(>0.5 \mathrm{M})$, the diffusion coefficient of $\mathrm{Na}^{+}$is smaller than that of $\mathrm{NH}_{4}{ }^{+}$, meaning 176 that the concentrated $\mathrm{Na}^{+}$does not only impede $\mathrm{NH}_{4}{ }^{+}$migration but also influence it self177 transport. For the dilution, the trend of the diffusion coefficient can be explained by the 
178 Nernst-Einstein equation that establishes the relationship between the molar limiting 179 conductivity $\left(\Lambda_{\mathrm{m}, \mathrm{i}^{0}}\right)$ and the diffusion coefficient $D_{i}[34]$.

$$
D_{i}=\frac{R T}{Z_{i}^{2} F^{2}} \Lambda_{m, i}^{0}
$$

181 where $z_{i}, T, F$, and $R$ are charge number of ion $i$, absolute temperature, Faraday's constant, 182 and the ideal gas constant, respectively. The diffusion coefficients linearly rely on the 183 molar limiting conductivity $\left(\Lambda_{\mathrm{m}, \mathrm{i}^{0}}\right)$. However, this formula becomes more complicated for 184 the concentrated solution. The diffusion coefficient is also related to the trajectories of 185 the particle [35]. Namely, the decreases of diffusion coefficients may be caused by the 186 charge neutralization in $\mathrm{OHP}[36,37]$. Apart from $\mathrm{Na}^{+}$and $\mathrm{NH}_{4}{ }^{+}$, water molecular should 187 not be ignored since the $\mathrm{H}-\mathrm{H}$ bond effect on the electronic structure is essential for 188 understanding the physical and chemical properties of the $\operatorname{EDL}[38,39]$. From the calculated 189 results of average MSD slope of water molecules using Einstein's equation, its diffusion 190 coefficient of $D_{\text {water, }} 7.5 \times 10^{-9} \mathrm{~m}^{2} \mathrm{~s}^{-1}$ indicates that water molecules have the largest 191 migration coefficient (Figure SI-3). This trend is because the self-diffusion and interdiffusion 192 coefficients decrease with an increase of salt concentration and water molecules in pure water 193 diffuse faster than in concentrated electrolyte. Our simulation results are in good 194 agreement with the study conducted by Kong et al. and Lyubartsev and Laaksonen [40, 195 41]. Therefore, the order of diffusion constants of $\mathrm{NH}_{4}^{+}, \mathrm{Na}^{+}$and water is $\mathrm{D}_{\text {water }}>\mathrm{D}_{\mathrm{Na}+}>$ $196 \mathrm{D}_{\mathrm{NH} 4+}$ in the diluted concentration, and $\mathrm{D}_{\text {water }}>\mathrm{D}_{\mathrm{NH} 4+}>\mathrm{D}_{\mathrm{Na}+}$ in the concentrated $\mathrm{Na}_{2} \mathrm{SO}_{4}$ 197 solution. 
The concentration distribution was described with mass density calculated via the mass

200 coordinate. Figure 4 shows the distributions of the mass density of $\mathrm{NH}_{4}{ }^{+}$and $\mathrm{Na}^{+}$along

201 the $x$-axis near the cathodic surface. Specifically, $\mathrm{NH}_{4}{ }^{+}$density increases to the most

202 significant peak $\left(0.016 \mathrm{~g} \mathrm{~cm}^{-3}\right)$, which is a compacted charge layer called the inner

203 Helmholtz plane (IHP) in the region nearest to the Pt surface [42, 43]. As the distance

204 extending to the bulk solution, $\mathrm{NH}_{4}{ }^{+}$density displays the second peak $\left(0.007 \mathrm{~g} \mathrm{~cm}^{-3}\right.$, on

205 average) that is considered the outer Helmholtz plane (OHP). When the distance extends

206 further away from the Pt surface, $\mathrm{NH}_{4}{ }^{+}$density stabilizes at $0.0045 \mathrm{~g} \mathrm{~cm}^{-3}$ in Figure $4(\mathrm{~b})$,

207 which is regarded as the diffusion layer (DL) [44]. The distribution profile of $\mathrm{Na}^{+}$has similar

208 peaks to that of $\mathrm{NH}_{4}{ }^{+}$along the $\mathrm{x}$-axis (Figure 4(d)), whereas the peak of $\mathrm{Na}^{+}$closest to the

209 Pt surface increases from $0 \mathrm{~g} \mathrm{~cm}^{-3}$ at $0 \mathrm{M}$ to $0.018 \mathrm{~g} \mathrm{~cm}^{-3}$ at $1.5 \mathrm{M}$ with the bulk $\mathrm{Na}_{2} \mathrm{SO}_{4}$

210 electrolyte concentrate. The comparison of the concentration distribution of $\mathrm{NH}_{4}{ }^{+}$and

$211 \mathrm{Na}^{+}$in Figures 4(c) and 4(d) shows that the $\mathrm{NH}_{4}{ }^{+}$density reduces from $0.016 \mathrm{~g} \mathrm{~cm}^{-3}$ to

$2120.003 \mathrm{~g} \mathrm{~cm}^{-3}$, which is significantly lower than that of $\mathrm{Na}^{+}$at the corresponding

213 concentration. The difference in the concentration distributions of $\mathrm{NH}_{4}^{+}$and $\mathrm{Na}^{+}$may

214 depend on the diffusion coefficient since the diffusion coefficient of $\mathrm{NH}_{4}{ }^{+}$is smaller than

215 that of $\mathrm{Na}^{+}$. Additionally, the concentration profiles of $\mathrm{NH}_{4}{ }^{+}$and $\mathrm{Na}^{+}$indicate that the

216 lowered peak of $\mathrm{NH}_{4}^{+}$is caused by the competitive increase of $\mathrm{Na}^{+}$concentration,

217 especially in the over-concentrated $\mathrm{Na}_{2} \mathrm{SO}_{4}$ electrolyte $(>0.5 \mathrm{M})$. The phenomena above

218 are related to the transient repulsion of ammonium $\left(\left[\mathrm{NH}_{4}{ }^{0}\right]_{\text {ads }}\right)$ and $\mathrm{Na}-\mathrm{H}_{2} \mathrm{O}$ hydration

219 "atmosphere" [45]. 
221 Ion transportation and accumulation forms an EDL around the electrodes. Figure 5(a) and $2225(b)$ illustrates the charge density profiles and the potential drop of $\mathrm{NH}_{4}{ }^{+}$and $\mathrm{Na}^{+}$in the

223 range of $0-1.5 \mathrm{M}$. There are two remarkable peaks $\left(0.0009\right.$ e $\AA^{-3}$ and 0.0004 e $\left.\AA^{-3}\right)$ 224 referring to the IHP and OHP of the $\mathrm{NH}_{4}{ }^{+}$charge density curve, in which the value of $\mathrm{NH}_{4}{ }^{+}$ 225 potential changes from $-0.0225 \mathrm{~V}$ to $0 \mathrm{~V}$ (Figure $5(\mathrm{c})$ and $5(\mathrm{~d})$ ). Integrating $\mathrm{NH}_{4}{ }^{+}$charge in

226 the $x$-axis, the charge density and potential drop of $\mathrm{NH}_{4}{ }^{+}$film decline from 0.0041 e $\AA^{-3}$ 227 and $-0.0226 \mathrm{~V}$ at $0 \mathrm{M}$ to 0.0006 e $\AA^{-3}$ and $-0.0151 \mathrm{~V}$ at $1.5 \mathrm{M}$, respectively, as summarized 228 in Table 2. $\mathrm{Na}^{+}$charge density increases and the potential escalating. However, the film 229 of $\mathrm{Na}^{+}$peaks disappear as $\mathrm{Na}_{2} \mathrm{SO}_{4}$ becomes over-concentrated.

230 All atoms with different charge always interact with each other in the aqueous condition.

231 Due to the negative charge carried by $\mathrm{O}$ in the $\mathrm{H}_{2} \mathrm{O}$ molecule, the total charge density and 232 potential drop shift from 0.0011 e $\AA^{-3}$ and $0.0095 \vee$ to -0.0228 e $\AA^{-3}$ and $-0.0449 \mathrm{~V}$, 233 respectively, (Figure SI-5 and Table 2). The variation of net charge density indicates the 234 importance of water molecule. As studied by Guo et al., water molecule at the interface 235 between the solution and electrodes forming hydrogen bonding changed the local 236 electronic structure of EDL [38]. The results gained by Velasco-Velez et al. elucidates that 237 the inert electrode surface can induce water molecules when the electrode is negatively 238 charged and therefore attracting the more positive $\mathrm{H}$ atoms [46].

239 Based on the total charge density and potential drop, the thicknesses of the $\mathrm{NH}_{4}{ }^{+}$layer 240 and $\mathrm{Na}^{+}$layer as the function of $\mathrm{Na}_{2} \mathrm{SO}_{4}$ concentration are calculated and summarized in 
241 Table 3. The total thickness of $\mathrm{NH}_{4}{ }^{+}$EDL experiences a slight increase from $19.0 \AA$ at $0 \mathrm{M}$

242 to $21.0 \AA$ at $1.5 \mathrm{M}$ but an apparent decrease to $16.0 \AA$ at $1.5 \mathrm{M}$. In the $\mathrm{Na}_{2} \mathrm{SO}_{4}$, the IHP

243 declines to $4.0 \AA$ from $6.0 \AA$; the OHP increases to $8.5 \AA$ at $0.25 \mathrm{M}$ but decreases to $6.5 \AA$

244 at $0.25 \mathrm{M}$; and DL varies from 5.5 to $7.0 \AA$. The comparison of IHP, OHP, and DL discloses

245 that $\mathrm{Na}_{2} \mathrm{SO}_{4}$ concentration has a greater influence on the Helmholtz layer (IHP and OHP)

246 than DL. The total thickness of $\mathrm{Na}^{+}$increases from $0 \AA$ at $0 \mathrm{M}$ to $23.5 \AA$ at $1.5 \mathrm{M}$. The HP

247 is thicker than the DL. These variations are mainly attributed to the excess accumulation

248 of ions from the diffusion layer and the insufficient supply of ions in the bulk solution [15,

$24947,48]$. Taking the thickness overlap of $\mathrm{NH}_{4}{ }^{+}$and $\mathrm{Na}^{+}$into consideration, the total EDL

250 thickness increases from $19.5 \AA$ at $0 \mathrm{M}$ to $23.5 \AA ̊$ at $1.5 \mathrm{M}$. According to the Debye-Hückel

251 equation, the charge density of $\mathrm{Na}^{+}$adsorption causes an increase of the $\mathrm{Na}^{+}$layer [49].

252 Therefore, the thick $\mathrm{Na}^{+}$layer blocks the rate of electron transfer of $\mathrm{NH}_{4}^{+}$reduction so

253 that the lack of an electron acceptor results in the decrease of the current density peak

254 of $\mathrm{NH}_{4}{ }^{+}$reduction.

\section{$255 \quad 3.3$ Ammonium reduction}

256 The differences of electric properties in charge density, potential drop, capacitance, and

257 thickness can reflect the kinetics of ion oxidation/reduction. To exam $\mathrm{NH}_{4}{ }^{+}$reduction at

258 the cathode interface of EDI, current-voltage and generated gas were measured. The

259 current-voltage curves were obtained at a $10.0 \mathrm{mV} \mathrm{s}^{-1}$ scanning rate under $0-1.5 \mathrm{M}$

$260 \mathrm{Na}_{2} \mathrm{SO}_{4}$ as supporting electrolyte (Figure 6). A single peak in the range of 0-0.8 $\mathrm{V}$ applied

261 voltage was observed on each curve. For forward scanning, the current density increases

262 to $0.005 \mathrm{~mA} \mathrm{~cm}^{-2}$ with $\mathrm{Na}_{2} \mathrm{SO}_{4}$ concentration increasing to $0.5 \mathrm{M}$ from $0 \mathrm{M}$. However, the 
263 forward current density does not continuously increase although the concentration of

$264 \mathrm{Na}_{2} \mathrm{SO}_{4}$ increases to $1.5 \mathrm{M}$. For backward scanning, the peak current decreases from $2650.023 \mathrm{~mA} \mathrm{~cm}{ }^{-2}$ to $-0.005 \mathrm{~mA} \mathrm{~cm}{ }^{-2}$, moving to the positive $y$-axis as the bulk $\mathrm{Na}_{2} \mathrm{SO}_{4}$ 266 electrolyte concentrating at $0.23 \mathrm{~V}$ (Figure 6(a)). The results are constant with that of the 267 experimental tests.

268 The generated gas was analyzed through gas chromatography and quantified through the 269 mass of nitrogen element. The plot shows that the mass in the liquid (anodic and cathodic) 270 is dominant, ammonia nitrogen takes second place and nitrogen gas is tiny (Figure 6(b)).

271 The changes of anodic- $\mathrm{N}$ and cathodic- $\mathrm{N}$ are because of migration. $\mathrm{NH}_{3}$ and $\mathrm{N}_{2}$ gas are 272 from $\mathrm{NH}_{4}^{+}$reduction (Eq.1) and base neutralization (Eq.2 and Eq.3).

$273 \mathrm{NH}_{4}{ }^{+}$reduction experiences the absorption of intermediates, $\left[\mathrm{NH}_{4}{ }^{0}\right]$ ads and $\mathrm{H}_{\mathrm{ads}}$. $\left[\mathrm{NH}_{4}{ }^{0}\right]_{\mathrm{ads}}$, 274 adsorbed Rydberg radicals and repulsed $\mathrm{NH}_{4}{ }^{+}$solvent molecules approaching for 275 additional binding so that the accumulation of $\left[\mathrm{NH}_{4}{ }^{0}\right]_{\text {ads }}$ in the EDL leads to the $\mathrm{NH}_{4}^{+}$ 276 concentration reducing [50-54].

$$
\mathrm{NH}_{4(a q)}^{+}+e^{-} \rightarrow\left[\mathrm{NH}_{4}^{0}\right]_{a d s}
$$

$$
\left[\mathrm{NH}_{4}^{0}\right]_{a d s} \rightarrow \mathrm{NH}_{3}^{*}+\mathrm{H}_{a d s}
$$

$$
\mathrm{NH}_{3}^{*} \rightarrow \mathrm{NH}_{2}{ }^{*}+\mathrm{H}_{\text {ads }}
$$

$$
2 N^{*} \rightarrow N_{2}+2^{*}
$$

282 where * is an active site. 
283 The first step is dominant, and the flowing steps process slowly so that the mass of

284 nitrogen gas is little. As integrating the experimental and theoretical results, we find

285 that the increase of the concentration of $\mathrm{Na}_{2} \mathrm{SO}_{4}$ electrolyte changes the current density

286 of ammonium reduction (from $-0.023 \mathrm{~mA} \mathrm{~cm}^{-2}$ to $-0.005 \mathrm{~mA} \mathrm{~cm}^{-2}$ at $0.23 \mathrm{~V}$ ).

\section{Conclusion}

288 This paper discussed the effects of $\mathrm{Na}_{2} \mathrm{SO}_{4}$ supporting electrolyte from $0 \mathrm{M}$ to $1.5 \mathrm{M}$ on $289 \mathrm{NH}_{4}{ }^{+}$reduction in the cathode surface of EDI using electrochemical analysis and MD 290 simulations. The results demonstrate that increasing the concentration of $\mathrm{Na}_{2} \mathrm{SO}_{4}$ 291 supporting electrolyte enhances the conductivity and total current but reduces ion 292 activity. The migration rates of $\mathrm{NH}_{4}{ }^{+}$and $\mathrm{Na}^{+}$increase in the dilute range (0-0.25 M) but a 293 decrease in the concentrated range $(>0.5 \mathrm{M})$. The fierce competitive adsorption of $\mathrm{Na}^{+}$ 294 forming a thick layer blocks $\mathrm{NH}_{4}{ }^{+}$migration and electron transportation in the EDL. $\mathrm{NH}_{4}{ }^{+}$ 295 reduction is weakened with the increase of $\mathrm{Na}_{2} \mathrm{SO}_{4}$ supporting electrolyte. Interestingly, 296 water molecules play a critical role in determining the net charge density and potential 297 drop. Therefore, the mechanisms presented in this manuscript disclose the function of 298 the co-ion concentration and the results can allow the manipulation of EDI capacity 299 optimization.

\section{Acknowledgements}

301 We acknowledge the support of various grants, including the Chongqing Science and Technology 302 Bureau (cstc2018jszX-zdyfxmX0016), Chongqing Ecology and Environment Bureau (2019-89) for 303 providing financial support. 


\section{References}

305 [1] L. Xu, F. Dong, H. Zhuang, W. He, M. Ni, S.P. Feng, P.H. Lee, Energy upcycle in anaerobic treatment: Ammonium, methane, and carbon dioxide reformation through a hybrid electrodeionization-solid oxide fuel cell system, Energy Conversion and Management 140 (2017) 157-166.

309 [2] O. Berkh, Y. Shacham-Diamand, E. Gileadi, Reduction of ammonium ion on Pt electrodes, Journal of The Electrochemical Society 155(10) (2008) F223-F229.

[3] D.J. Little, M.R. Smith III, T.W. Hamann, Electrolysis of liquid ammonia for hydrogen generation, Energy \& Environmental Science 8(9) (2015) 2775-2781.

[4] E. Simons, E. Cairns, D. Surd, The performance of direct ammonia fuel cells, Journal of The Electrochemical Society 116(5) (1969) 556-561.

[5] L. Xu, F. Dong, H. Zhuang, W. He, M. Ni, S.-P. Feng, P.-H. Lee, Energy upcycle in anaerobic treatment: Ammonium, methane, and carbon dioxide reformation through a hybrid electrodeionization-solid oxide fuel cell system, Energy Conversion and Management 140 (2017) 157-166.

[6] L. Alvarado, A. Chen, Electrodeionization: principles, strategies and applications, Electrochimica Acta 132 (2014) 583-597.

[7] S.-H. Moon, S.-H. Yun, Process integration of electrodialysis for a cleaner environment, Current Opinion in Chemical Engineering 4 (2014) 25-31.

[8] I. Wenten, K. Khoiruddin, P. Aryanti, A. Hakim, Scale-up Strategies for Membrane-Based

Desalination Processes: A Review, Journal of Membrane Science and Research 2(2) (2016) 42-58.

[9] M.P. Mousavi, B.E. Wilson, S. Kashefolgheta, E.L. Anderson, S. He, P. Bu“hlmann, A. Stein, Ionic Liquids as Electrolytes for Electrochemical Double-Layer Capacitors: Structures that Optimize Specific Energy, ACS Applied Materials \& Interfaces 8(5) (2016) 3396-3406.

[10] J. Goodenough, H. Abruna, M. Buchanan, Basic Research Needs for Electrical Energy Storage. Report of the Basic Energy Sciences Workshop on Electrical Energy Storage, April 2-4, 2007, DOESC (USDOE Office of Science (SC)), 2007.

[11] E.J. Olson, P. Bühlmann, Unbiased Assessment of Electrochemical Windows: Minimizing Mass Transfer Effects on the Evaluation of Anodic and Cathodic Limits, Journal of The Electrochemical Society 160(2) (2013) A320-A323.

\section{[12] A. Casadellà, O. Schaetzle, K. Nijmeijer, K. Loos, Polymer inclusion membranes (PIM) for the} recovery of potassium in the presence of competitive cations, Polymers 8(3) (2016) 76.

[13] Y. Liu, M. Qin, S. Luo, Z. He, R. Qiao, Understanding ammonium transport in bioelectrochemical systems towards its recovery, Scientific Reports 6 (2016).

338 [14] S.D. Rosasco, J.L. Stickney, G.N. Salaita, D.G. Frank, J.Y. Katekaru, B.C. Schardt, M.P. Soriaga, D.A. 339 Stern, A.T. Hubbard, Cation competition in the electrical double-layer at a well-defined electrode 340 surface $\mathrm{Li}+, \mathrm{Na}+, \mathrm{K}+, \mathrm{Cs}+, \mathrm{H}+, \mathrm{Mg} 2+, \mathrm{Ca} 2+, \mathrm{Ba} 2+, \mathrm{La} 3+$, tetramethylammonium, choline and 341 acetylcholine cations at Pt (111) surfaces containing an ordered layer of cyanide, Journal of

342 Electroanalytical Chemistry And Interfacial Electrochemistry 188(1-2) (1985) 95-104.

343 [15] C. Cagle, G. Feng, R. Qiao, J. Huang, B.G. Sumpter, V. Meunier, Structure and charging kinetics of 344 electrical double layers at large electrode voltages, Microfluidics and Nanofluidics 8(5) (2010) 703 345708

346 [16] G. Jiang, C. Cheng, D. Li, J.Z. Liu, Molecular dynamics simulations of the electric double layer 347 capacitance of graphene electrodes in mono-valent aqueous electrolytes, Nano Research 9(1) (2016) 348 174-186. 
[17] A. Yoshida, K. Imoto, Electric double layer capacitor and method for producing the same,

350 Google Patents, 1992.

351 [18] S. Yoon, J.H. Jang, H.K. Bok, S.M. Oh, Complex capacitance analysis on rate capability of electric-

352 double layer capacitor (EDLC) electrodes of different thickness, Electrochimica Acta 50(11) (2005)

$353 \quad 2255-2262$.

354 [19] M. Vossen, F. Forstmann, Integral equation theory for the electrode-electrolyte interface with the central force water model. Results for an aqueous solution of sodium chloride, Molecular Physics 86(6) (1995) 1493-1516.

[20] Z. Ma, M. Wang, X. Gao, C. Gao, Charge and separation characteristics of nanofiltration membrane embracing dissociated functional groups, Frontiers of Environmental Science \& Engineering 8(5) (2014) 650-658.

[21] S. Alexey, M. Jr, A. D, Competition among $\mathrm{Li}+, \mathrm{Na}+, \mathrm{K}+$, and $\mathrm{Rb}+$ monovalent ions for DNA in molecular dynamics simulations using the additive CHARMM36 and Drude polarizable force fields, The Journal of Physical Chemistry B 119(12) (2015) 4428-4440.

[22] P. Soroosh, L. Hai, Molecular dynamics simulations of ion solvation by flexible-boundary QM/MM: On-the-fly partial charge transfer between QM and MM subsystems, Journal of Computational Physics 35(24) (2014) 1778-1788.

[23] J.P. Soetardji, J.C. Claudia, Y.-H. Ju, J.A. Hriljac, T.-Y. Chen, F.E. Soetaredjo, S.P. Santoso, A. Kurniawan, S. Ismadji, Ammonia removal from water using sodium hydroxide modified zeolite mordenite, Rsc Advances 5(102) (2015) 83689-83699.

[24] L. Joly, C. Ybert, E. Trizac, L. Bocquet, Hydrodynamics within the electric double layer on slipping surfaces, Physical Review Letters 93(25) (2004) 257805.

[25] J.W. Lee, J.A. Templeton, K.K. Mandadapu, J.A. Zimmerman, Comparison of molecular and primitive solvent models for electrical double layers in nanochannels, Journal of Chemical Theory and Computation 9(7) (2013) 3051-3061.

[26] S. Plimpton, Fast parallel algorithms for short-range molecular dynamics, Journal of Computational Physics 117(1) (1995) 1-19.

[27] J.-P. Ryckaert, G. Ciccotti, H.J. Berendsen, Numerical integration of the cartesian equations of motion of a system with constraints: molecular dynamics of $n$-alkanes, Journal of Computational Physics 23(3) (1977) 327-341.

[28] D.A. Skoog, D.M. West, F.J. Holler, S. Crouch, Fundamentals of analytical chemistry, Nelson Education2013.

[29] J. Kielland, Individual activity coefficients of ions in aqueous solutions, Journal of the American Chemical Society 59(9) (1937) 1675-1678.

[30] A. Alp, A. Nain, N. Kumar, M. Ibrahim, Density and viscosity of magnesium sulphate in formamide+ ethylene glycol mixed solvents, Journal of Chemical Sciences 114(5) (2002) 495-500. [31] A. Korosi, B. Fabuss, VISCOSITIES OF BINARY AQUEOUS SOLUTIONS OF NACL KCL NA2SO4 AND MGSO4 AT CONCENTRATIONS AND TEMPERATURES OF INTEREST IN DESALINATION PROCESSES, Journal of chemical and engineering data 13(4) (1968) 548-\&.

[32] A. Bald, Z. Kinart, R. Tomaš, Viscosity Coefficients of KCl, NaCl, Nal, KNO 3, LiNO 3, NaBPh 4 and Bu $4 \mathrm{NI}$ in Water-Dimethyl Sulfoxide Binary Mixtures With a Low Organic Solvent Content, Croatica Chemica Acta 89(3) (2016) 345-353.

[33] S. Trasatti, Atkins' Physical Chemistry, P. Atkins, J. De Paula, Oxford University Press, Oxford, UK (2006), ISBN: 0198700725, Pergamon, 2007.

[34] D. Frenkel, B. Smit, Understanding molecular simulation: from algorithms to applications, Academic press 2001. 
[35] D.C. Rapaport, D.C.R. Rapaport, The art of molecular dynamics simulation, Cambridge university press2004.

[36] S.W. Feldberg, On the dilemma of the use of the electroneutrality constraint in electrochemical calculations, Electrochemistry Communications 2(7) (2000) 453-456.

[37] E.M. Ney, Electrical Double Layer Potential Distribution in Nanoporous Electrodes from Molecular Modeling and Classical Electrodynamics Analysis, (2016). [38] J.-H. Guo, Y. Luo, A. Augustsson, J.-E. Rubensson, C. Såthe, H. Ågren, H. Siegbahn, J. Nordgren, $\mathrm{X}$-ray emission spectroscopy of hydrogen bonding and electronic structure of liquid water, Physical review letters 89(13) (2002) 137402.

[39] P.L. Silvestrelli, M. Parrinello, Structural, electronic, and bonding properties of liquid water from first principles, The Journal of chemical physics 111(8) (1999) 3572-3580.

[40] J. Kong, Z. Bo, H. Yang, J. Yang, X. Shuai, J. Yan, K. Cen, Temperature dependence of ion diffusion coefficients in nacl electrolyte confined within graphene nanochannels, Physical Chemistry Chemical Physics 19(11) (2017) 7678-7688.

[41] A.P. Lyubartsev, A. Laaksonen, Concentration effects in aqueous $\mathrm{NaCl}$ solutions. A molecular dynamics simulation, The Journal of Physical Chemistry 100(40) (1996) 16410-16418.

[42] S. Krishnamurthy, P. Bhattacharya, P. Phelan, R. Prasher, Enhanced mass transport in nanofluids, Nano Letters 6(3) (2006) 419-423.

[43] B.N. Pal, B.M. Dhar, K.C. See, H.E. Katz, Solution-deposited sodium beta-alumina gate dielectrics for low-voltage and transparent field-effect transistors, Nature Materials 8(11) (2009) 898.

[44] M. Belonenko, N. Lebedev, S. Sudorgin, Electrical conductivity and diffusion coefficient of electrons in a graphene bilayer, Technical Physics 57(7) (2012) 1025-1029.

[45] H. Lim, W. Lu, X. Chen, Y. Qiao, Effects of ion concentration on thermally-chargeable doublelayer supercapacitors, Nanotechnology 24(46) (2013) 465401.

[46] J.-J. Velasco-Velez, C.H. Wu, T.A. Pascal, L.F. Wan, J. Guo, D. Prendergast, M. Salmeron, The structure of interfacial water on gold electrodes studied by $\mathrm{x}$-ray absorption spectroscopy, Science 346(6211) (2014) 831-834.

[47] E.M. Evleth, E. Kassab, Role of Rydberg radicals in electrochemistry, Pure and Applied Chemistry 60(2) (1988) 209-214.

[48] K. Laidler, J. Meiser, B. Sanctuary, Physical Chemistry 2003, Houghton Mifflin: Boston, MA. [49] N. Kallay, T. Preočanin, D. Kovačević, J. Lützenkirchen, E. Chibowski, Electrostatic potentials at solid/liquid interfaces, Croatica chemica acta 83(3) (2010) 357-370.

[50] M. Morita, T. Kaigaishi, N. Yoshimoto, M. Egashira, T. Aida, Effects of the electrolyte composition on the electric double-layer capacitance at carbon electrodes, Electrochemical and Solid-state Letters 9(8) (2006) A386-A389.

[51] K. Kordesch, J. Gsellmann, M. Cifrain, S. Voss, V. Hacker, R.R. Aronson, C. Fabjan, T. Hejze, J. Daniel-Ivad, Intermittent use of a low-cost alkaline fuel cell-hybrid system for electric vehicles, J. Power Sources 80(1) (1999) 190-197.

[52] N. Dekker, G. Rietveld, Highly efficient conversion of ammonia in electricity by solid oxide fuel cells, J. Compos. Tech. Res. 3(4) (2006) 499-502.

[53] A. Fuerte, R. Valenzuela, M. Escudero, L. Daza, Ammonia as efficient fuel for SOFC, J. Power Sources 192(1) (2009) 170-174.

[54] M. Boudart, G. Djéga-Mariadassou, Kinetics of heterogeneous catalytic reactions, Princeton University Press2014. 
Figures

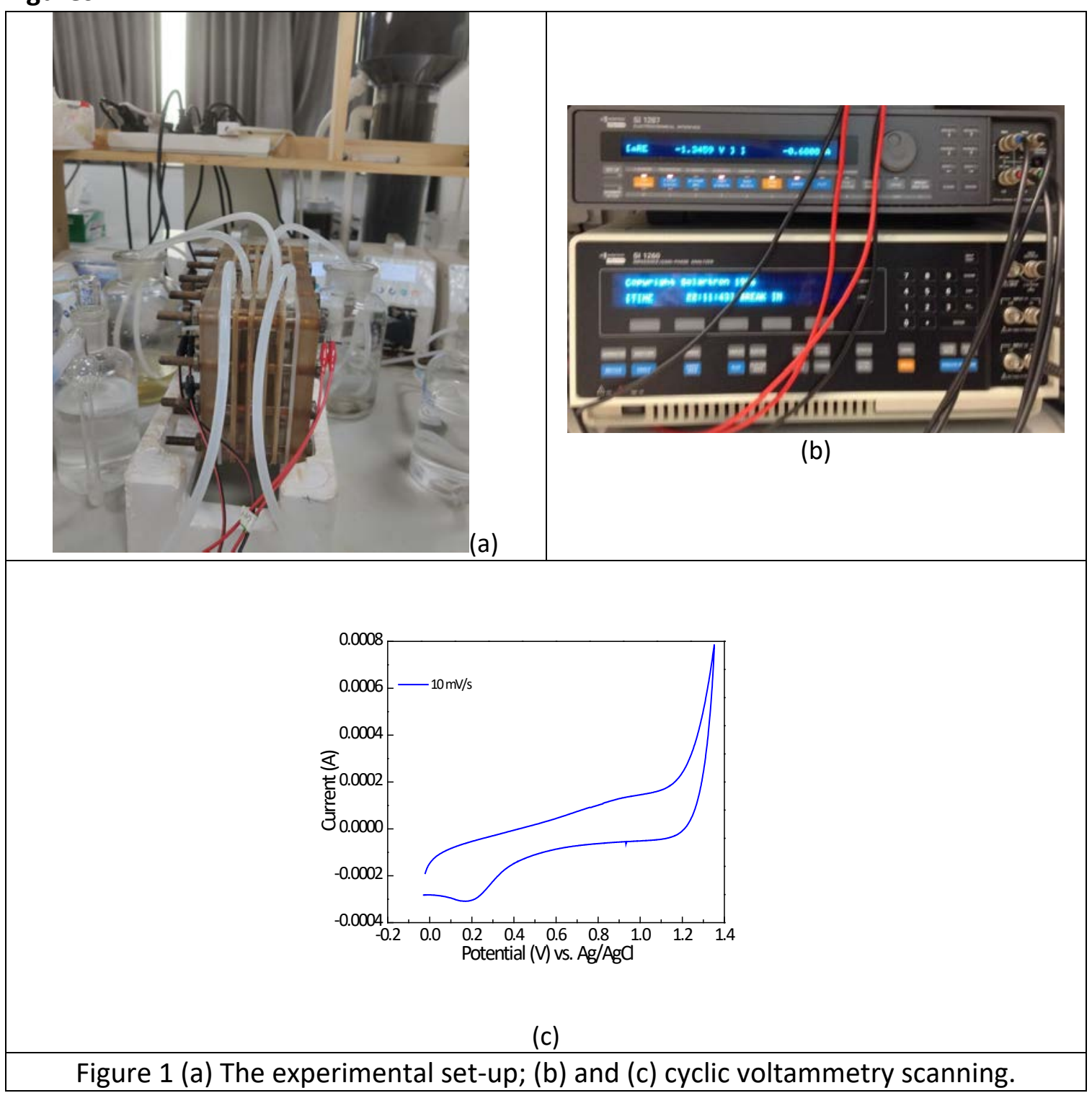




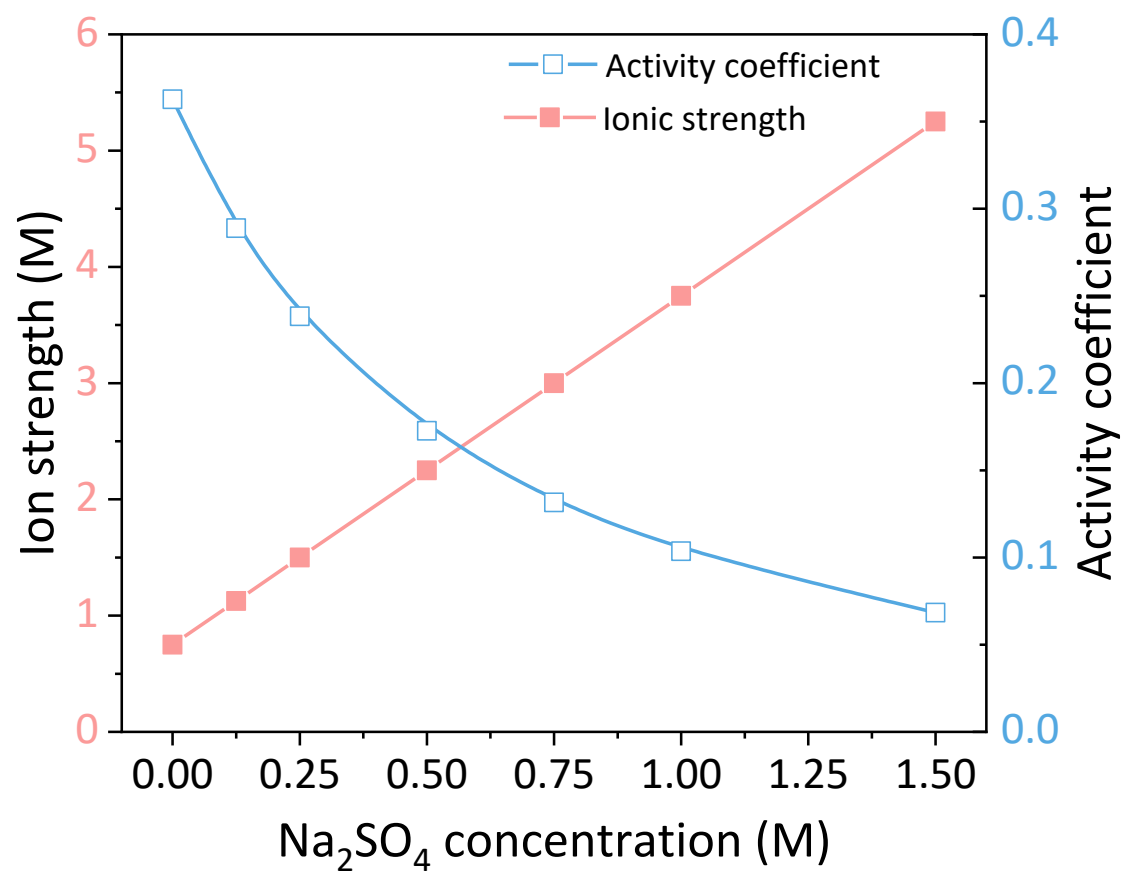

(a)

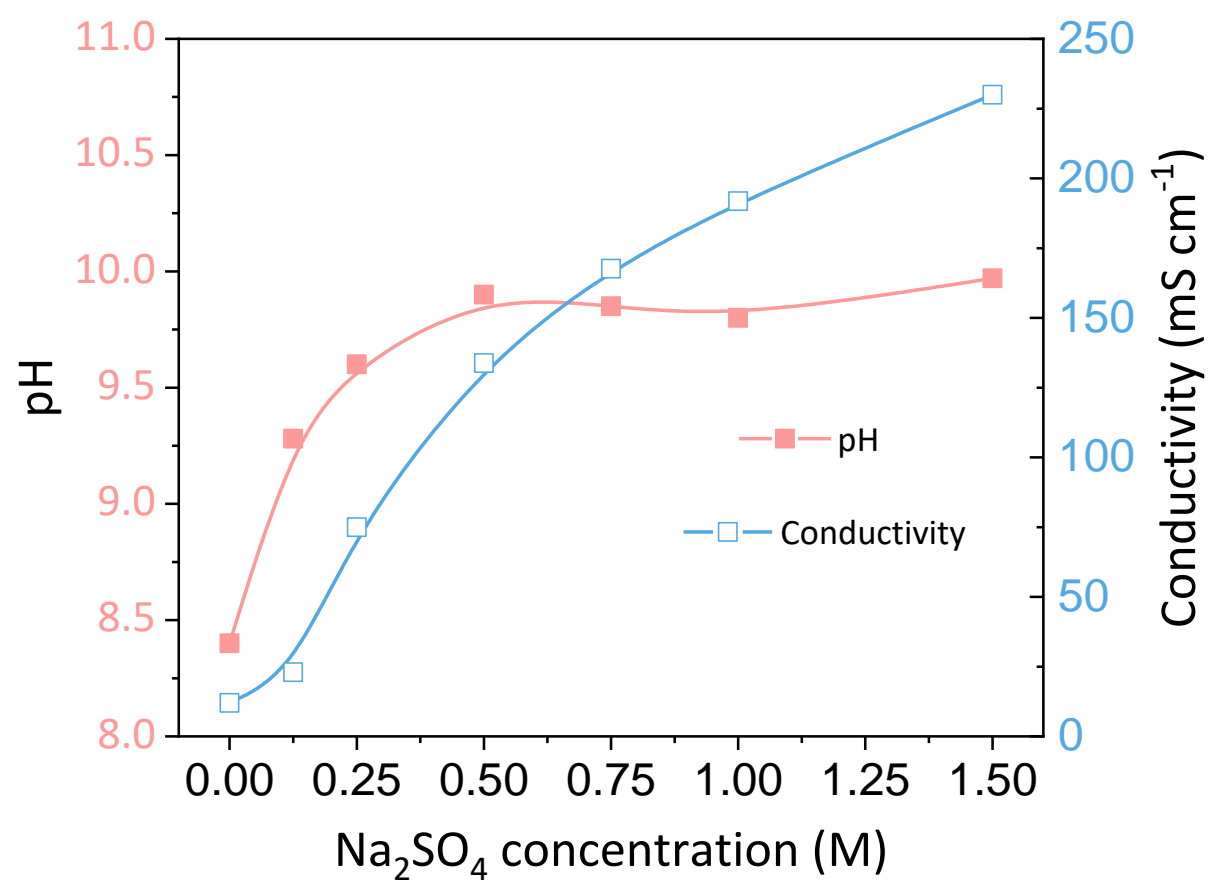

(b)

Figure 2 Characteristics of solution at 0-1.5 $\mathrm{M} \mathrm{Na}_{2} \mathrm{SO}_{4}$ electrolyte. (a)lon strength and activity coefficient of $\mathrm{NH}_{4}^{+}$; (b) $\mathrm{pH}$ and conductivity 


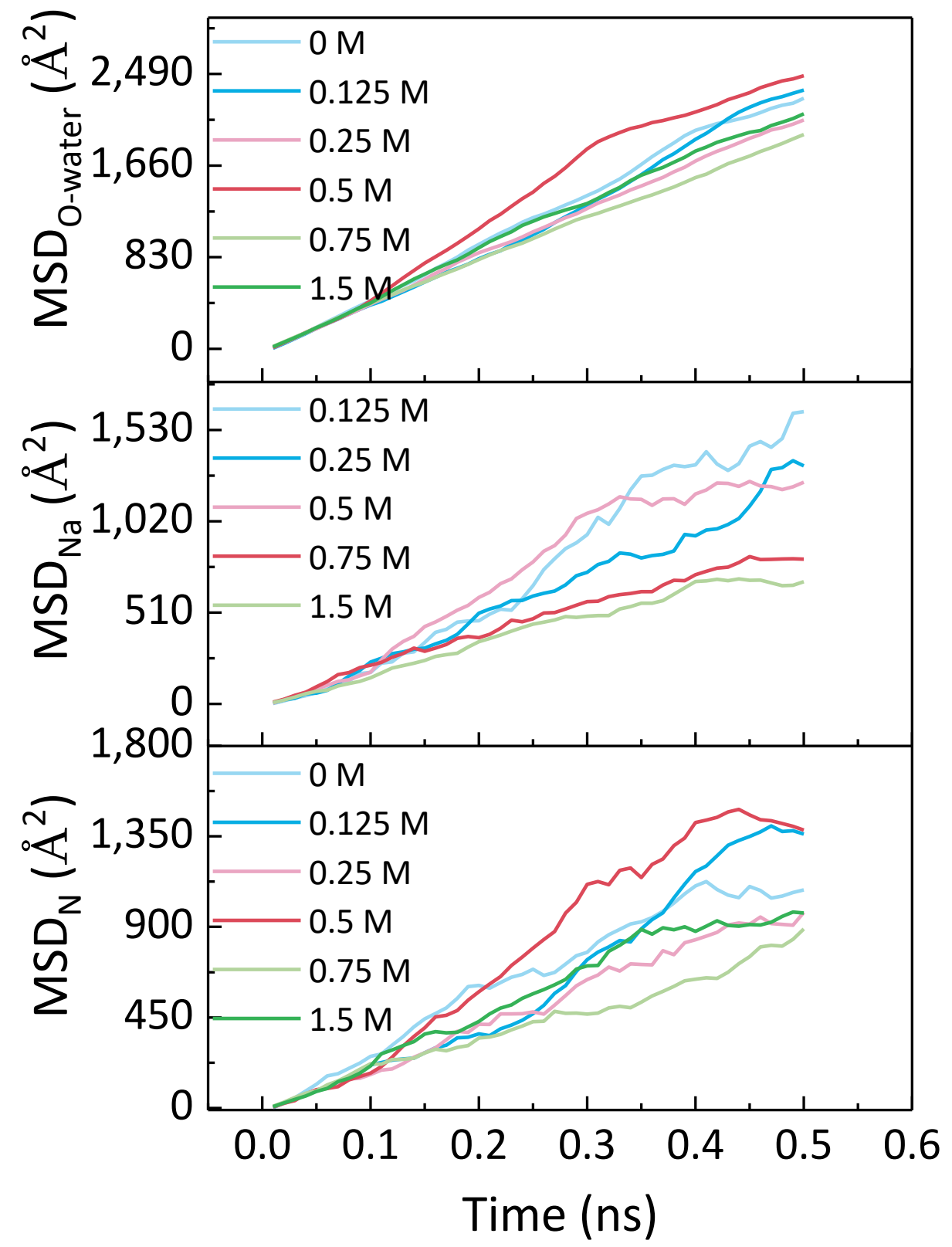

(a) 


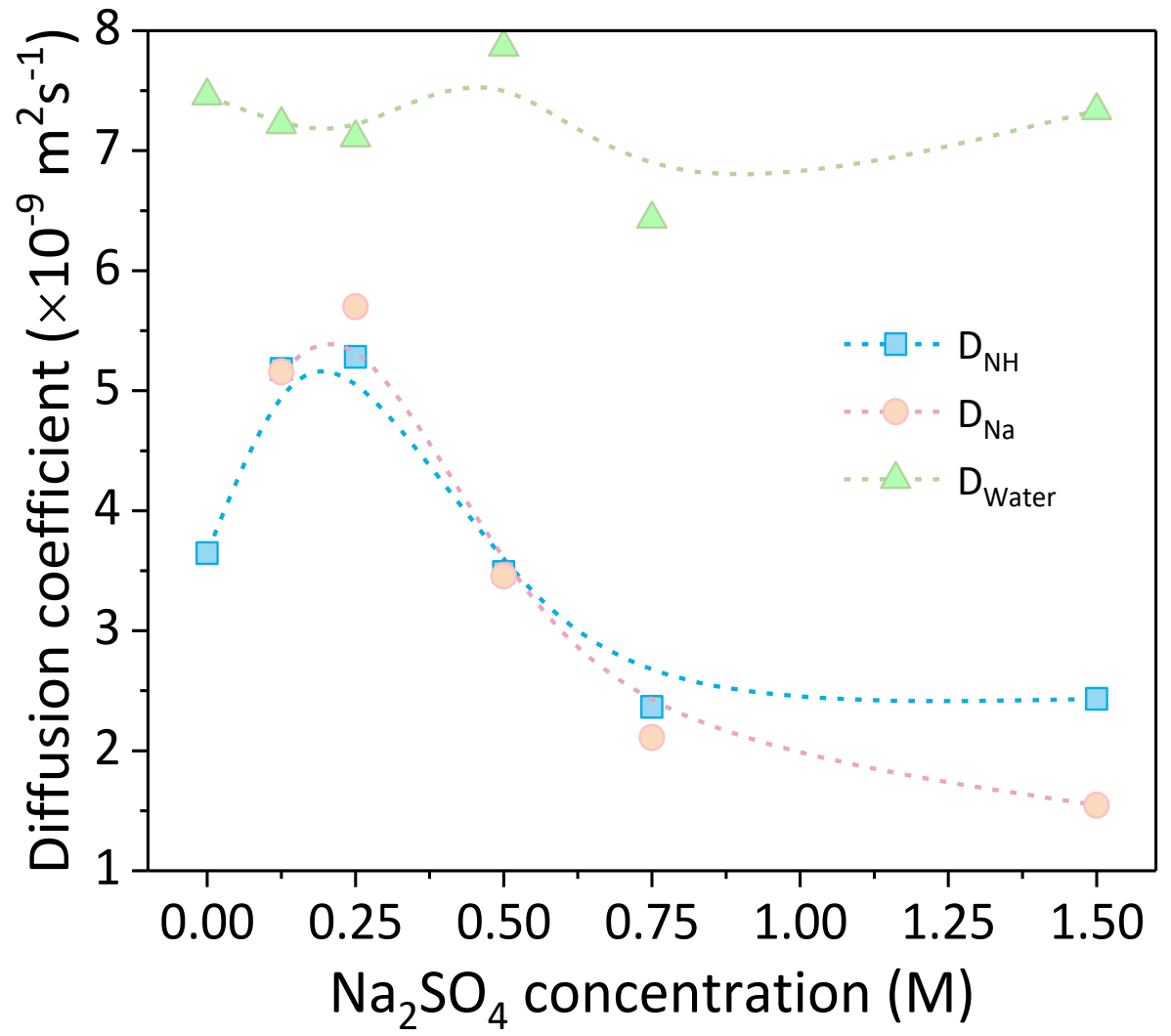

(b)

Figure 3 (a) MSD values of N, Na and O-water in $0.5 \mathrm{~ns}$; (b) diffusion rates of $\mathrm{NH}_{4}^{+}, \mathrm{Na}^{+}$ and $\mathrm{H}_{2} \mathrm{O}$ molecules as a function of $\mathrm{Na} 2 \mathrm{SO} 4$ concentration. 

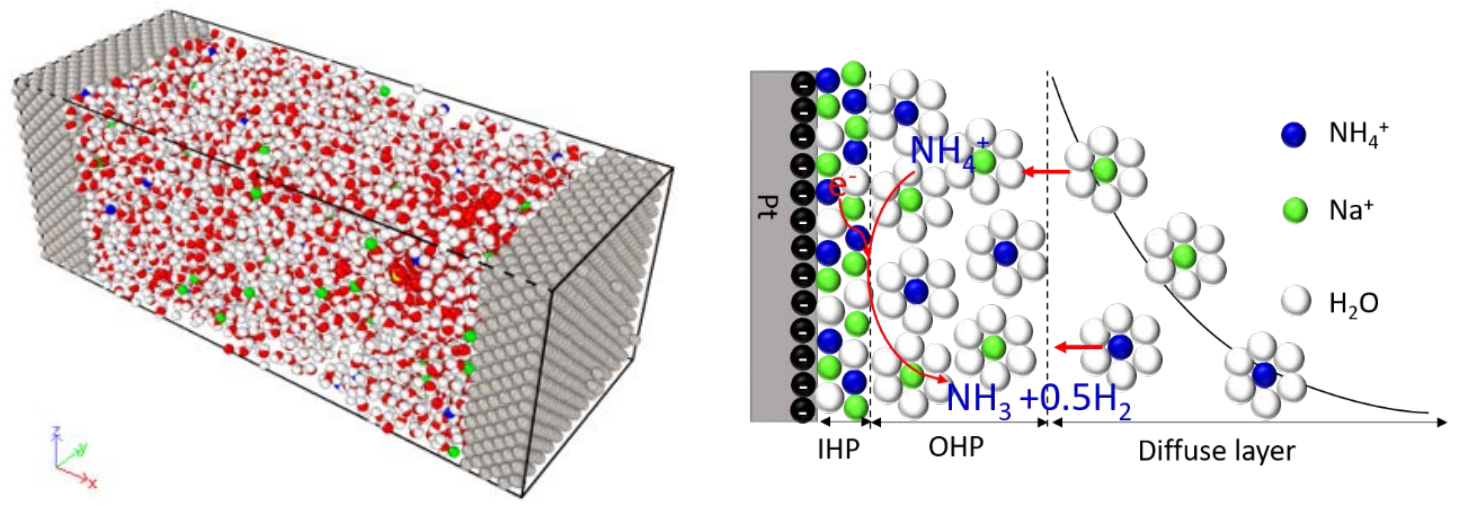

(a)

(b)

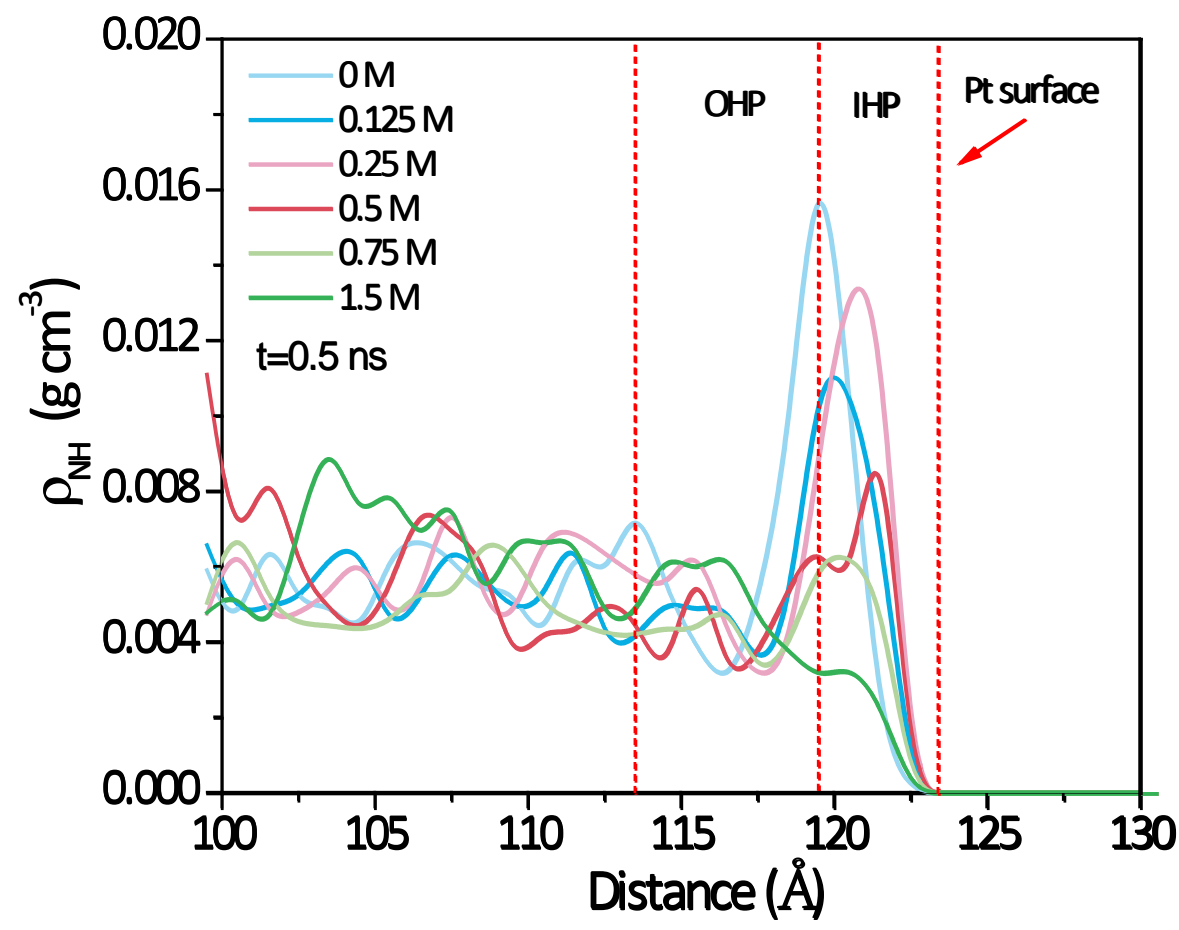

(c) 


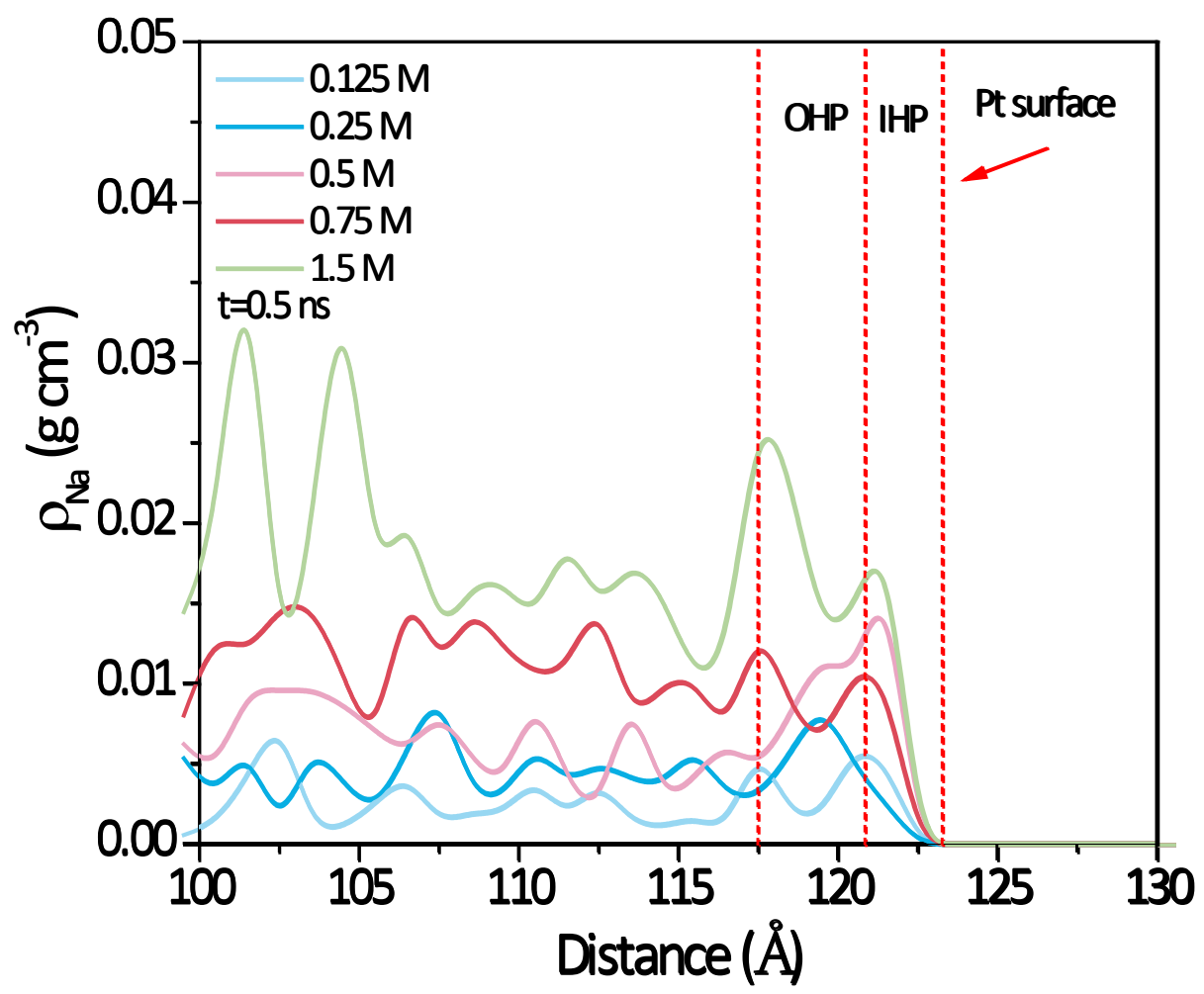

(d)

Figure 4 (a) Single channel model of electrodeionization; (b) $\mathrm{NH}_{4}{ }^{+}$EDL film; (c) and (d) concentration profiles of $\mathrm{NH}_{4}{ }^{+}$and $\mathrm{Na}^{+}$as a function of $\mathrm{Na}_{2} \mathrm{SO}_{4}$ concentration (0-1.5 M). 


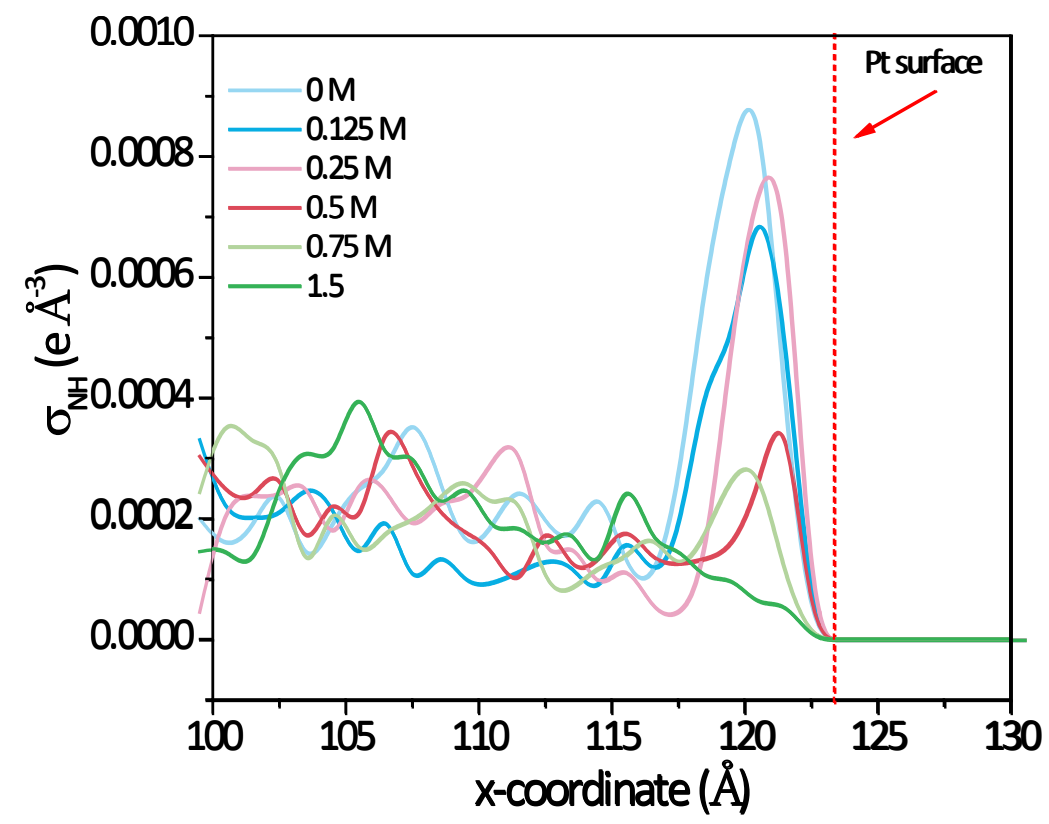

(a)

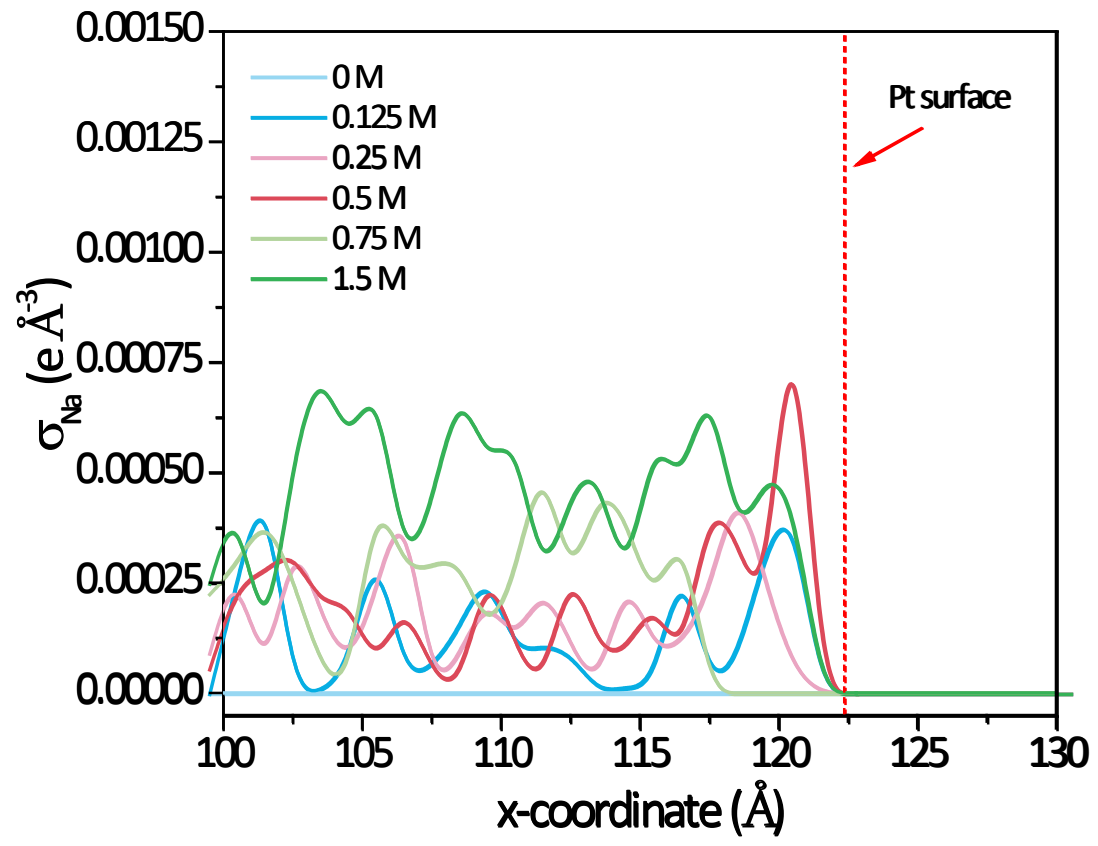

(b) 


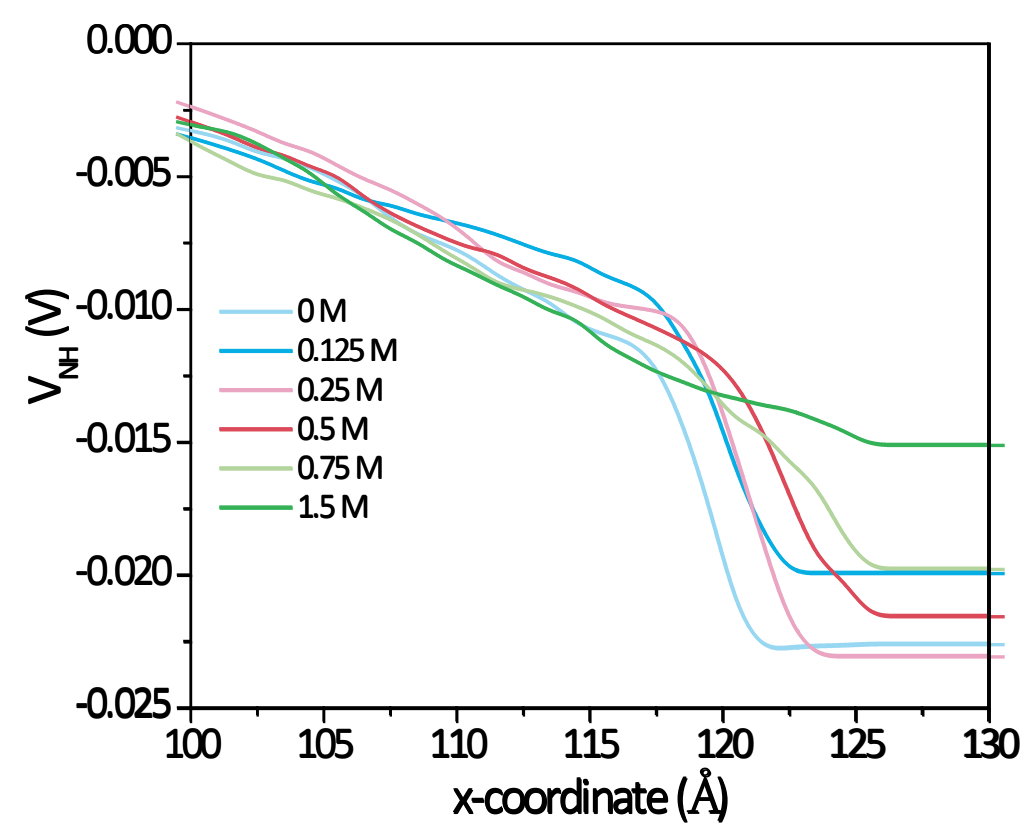

(c)

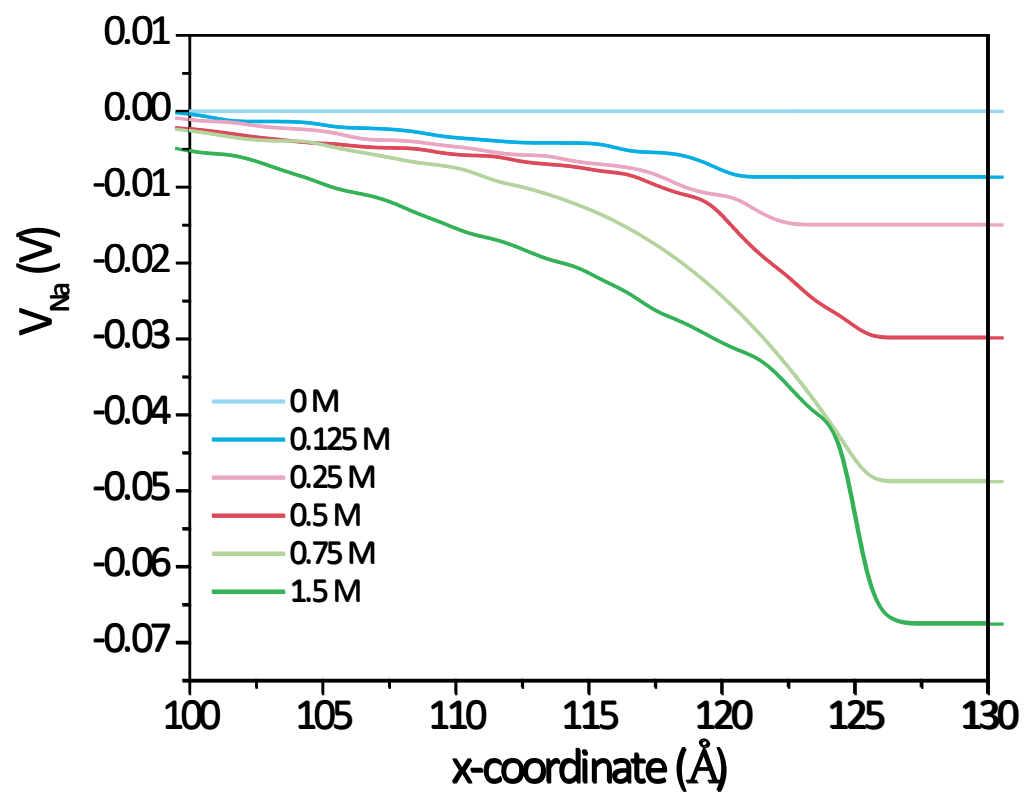

(d)

Figure 5 (a) and (b) Charge density distributions; (c) and (d) potential drops of $\mathrm{NH}_{4}{ }^{+}$ and $\mathrm{Na}^{+}$along the $\mathrm{x}$-axis under $0-1.5 \mathrm{M} \mathrm{Na}_{2} \mathrm{SO}_{4}$.

Figure 5 (a) and (b) Charge density distributions; (c) and (d) potential drops of $\mathrm{NH}_{4}^{+}$and $\mathrm{Na}^{+}$along the $x$-axis under $0-1.5 \mathrm{M} \mathrm{Na}_{2} \mathrm{SO}_{4}$. 


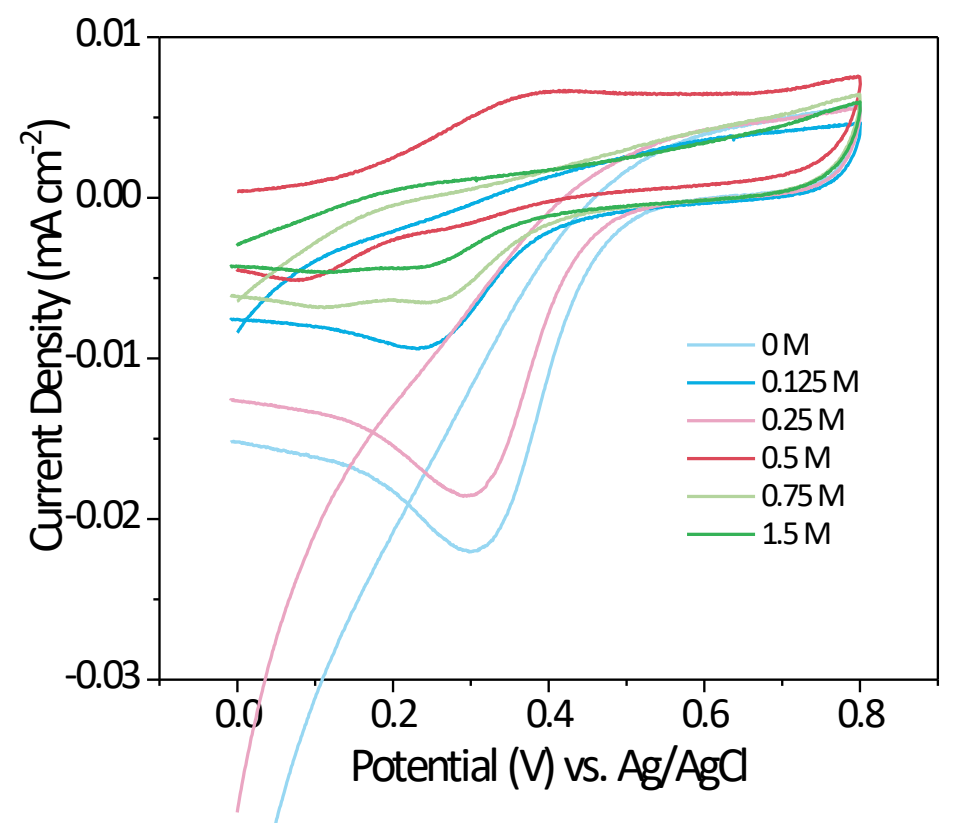

(a)

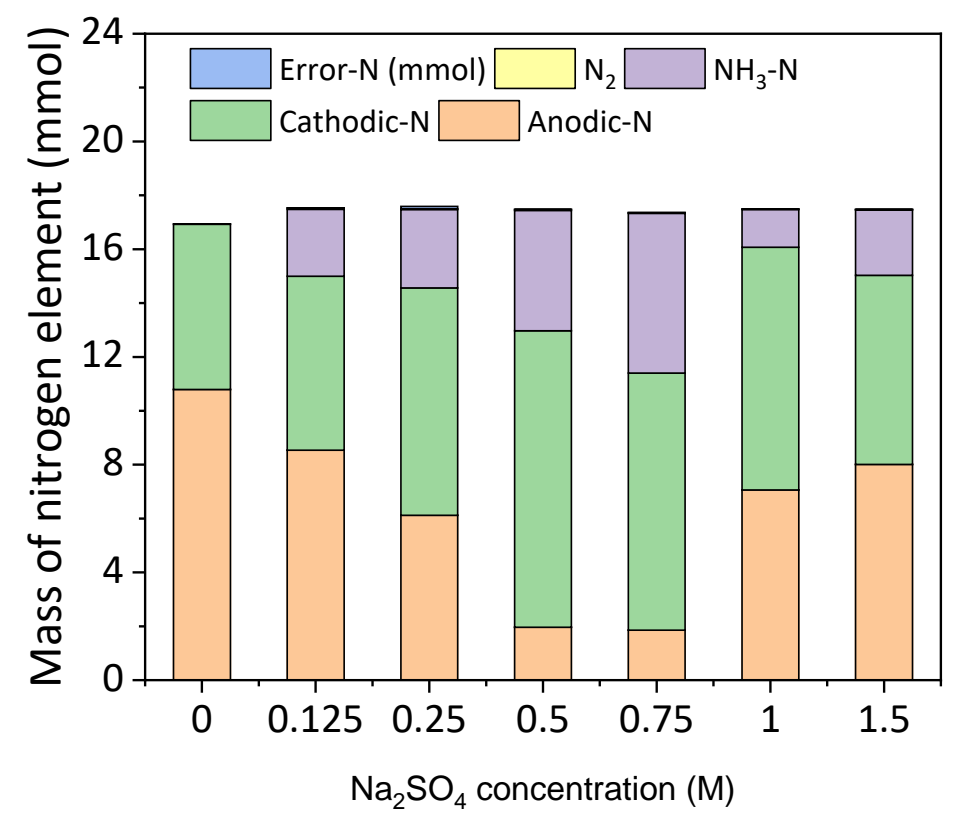

(b)

Figure 6 (a) Current-Voltage curves at 0-1.5 $\mathrm{M} \mathrm{Na}_{2} \mathrm{SO}_{4}$; (b) Nitrogen constituents. 


\section{Tables}

Table 1 Mobility and transport numbers of $\mathrm{NH}_{4}{ }^{+}, \mathrm{Na}^{+}$and $\mathrm{SO}_{4}{ }^{2-}$ at $0-1.5 \mathrm{M} \mathrm{Na}_{2} \mathrm{SO}_{4}$

\begin{tabular}{|c|c|c|c|c|c|c|}
\hline \multirow{2}{*}{$\begin{array}{c}\mathrm{Na}_{2} \mathrm{SO}_{4} \text { concentration } \\
\mathrm{mol} \mathrm{L}^{-1}\end{array}$} & \multicolumn{3}{|c|}{ Mobility } & \multicolumn{3}{|c|}{ Transport number } \\
\hline & $\mathrm{NH}_{4}^{+}$ & $\mathrm{Na}^{+}$ & $\mathrm{SO}_{4}^{2-}$ & $\mathrm{NH}_{4}^{+}$ & $\mathrm{Na}^{+}$ & $\mathrm{SO}_{4}{ }^{2-}$ \\
\hline 0 & 1.01 & - & 3.29 & 0.67 & - & 0.33 \\
\hline 0.125 & 1.49 & 4.06 & 2.03 & 0.17 & 0.33 & 0.50 \\
\hline 0.25 & 1.33 & 3.40 & 1.70 & 0.17 & 0.42 & 0.41 \\
\hline 0.50 & 1.29 & 2.78 & 1.39 & 0.11 & 0.63 & 0.26 \\
\hline 0.75 & 1.34 & 2.45 & 1.22 & 0.11 & 0.63 & 0.26 \\
\hline 1.00 & 1.37 & 1.87 & 0.93 & 0.08 & 0.65 & 0.27 \\
\hline 1.50 & 1.27 & 1.63 & 0.81 & 0.08 & 0.64 & 0.28 \\
\hline
\end{tabular}


Table 2 Electric properties of $\mathrm{NH}_{4}{ }^{+}$film and EDL capacitance via MD

\begin{tabular}{|c|c|c|c|c|c|c|c|c|c|}
\hline \multirow{2}{*}{$\begin{array}{c}\mathrm{Na}_{2} \mathrm{SO}_{4} \\
\text { concentration } \\
\mathrm{mol} \mathrm{L}^{-1}\end{array}$} & \multicolumn{4}{|c|}{$\begin{array}{c}\text { Charge density } \\
\text { e } \AA^{-3}\end{array}$} & \multicolumn{4}{|c|}{$\begin{array}{c}\text { Potential drop } \\
\text { V }\end{array}$} & \multirow{2}{*}{$\begin{array}{c}\text { EDL } \\
\text { capacitance } \\
\times 10^{-19} \mathrm{~F}^{-3}\end{array}$} \\
\hline & $\mathrm{NH}_{4}{ }^{+}$ & $\mathrm{Na}^{+}$ & $\mathrm{H}_{2} \mathrm{O}$ & Total & $\mathrm{NH}_{4}{ }^{+}$ & $\mathrm{Na}^{+}$ & $\mathrm{H}_{2} \mathrm{O}$ & Total & \\
\hline 0 & 0.0041 & 0.0000 & -0.0030 & 0.0011 & -0.0226 & 0.0 & 0.0321 & 0.0095 & 0.1795 \\
\hline 0.125 & 0.0030 & 0.0013 & -0.0083 & -0.0040 & -0.0220 & -0.0086 & 0.0252 & -0.0054 & 1.1920 \\
\hline 0.25 & 0.0026 & 0.0015 & -0.0125 & -0.0083 & -0.0230 & -0.0149 & 0.0231 & -0.0149 & 0.8939 \\
\hline 0.5 & 0.0016 & 0.0024 & -0.0235 & -0.0194 & -0.0215 & -0.0298 & 0.0262 & -0.0251 & 1.2363 \\
\hline 0.75 & 0.0013 & 0.0010 & -0.0312 & -0.0290 & -0.0198 & -0.0487 & 0.0276 & -0.0409 & 1.1321 \\
\hline 1.5 & 0.0006 & 0.0031 & -0.0265 & -0.0228 & -0.0151 & -0.0645 & 0.0347 & -0.0449 & 0.8117 \\
\hline
\end{tabular}


Table 3 EDL structures and thicknesses $\left(\mathrm{NH}_{4}{ }^{+}\right.$and $\left.\mathrm{Na}^{+}\right)$via $\mathrm{MD}$

\begin{tabular}{cccccccc}
$\begin{array}{c}\mathrm{Na}_{2} \mathrm{SO}_{4} \\
\text { concentration } \\
\mathrm{mol} \mathrm{L}^{-1}\end{array}$ & IHP & OHP & DL & IHP & OHP & DL & \\
\hline 0 & 6.0 & 7.5 & 5.5 & -- & -- & -- & 19.0 \\
0.125 & 5.5 & 8.0 & 6.0 & 4.5 & 4.0 & 7.5 & 19.5 \\
0.25 & 5.5 & 8.5 & 7.0 & 6.0 & 6.0 & 6.5 & 21.0 \\
0.5 & 5.0 & 7.0 & 5.0 & 8.5 & 8.5 & 7.0 & 24.0 \\
0.75 & 5.0 & 6.5 & 6.0 & 8.0 & 7.0 & 6.0 & 21.0 \\
1.5 & 4.0 & 6.5 & 5.5 & 7.5 & 8.5 & 7.5 & 23.5 \\
\hline
\end{tabular}

